\title{
Coronary Artery bypass grafting and/or valvular surgery in patients with previous pneumonectomy
}

\author{
Alexander Fragkidis, Alexander Dimitriou and Dimitrios Dougenis*
}

\begin{abstract}
There is a lack of data regarding heart surgery on patients who have been previously pneumectomized. These patients pose unique challenges and surgical management may necessitate deviations from standard methods in the perioperative course. To summarize the available knowledge and to assess the optimal methods, we reviewed all reported patients with prior pneumonectomy who were subjected to coronary artery bypass grafting and/or valve surgery.

In a Medline search from 1966 to May 2011 carefully undertaken, we identified 22 articles, including 29 patients who underwent 30 operations: CABG 70\%, valvular surgery 23\%, and combination 7\%. Severe morbidity was 37\% and 30-day mortality $13 \%$.

Although postoperative morbidity and mortality remain higher in previously pneumectomized patients undergoing coronary artery bypass grafting and valvular surgery, the gathered experience up to date suggests that a carefully planned surgical strategy, along with the use of advanced modern techniques may reduce morbidity and improve final outcome.
\end{abstract}

\section{Background}

Previous pneumonectomy is a rare comorbidity among patients undergoing open heart surgery for ischemic or valvular heart disease and poses unique intraoperative and postoperative challenges. Although several authors have proposed experience-based standards and considerations concerning surgical strategies for these patients, official guidelines have yet to be established. In this study, our aim was to review the current data and established suggestions and general principles in cardiac surgery on the pneumectomized patients.

\section{Methods}

We conducted a MEDLINE search from 1966 to May 2011 for available literature on patients with previous pneumonectomy who underwent open heart surgery for coronary artery bypass grafting (CABG) and/or valve repair or replacement, alone or in combination. The collected data was evaluated in detail and the site of

\footnotetext{
*Correspondence: ddougen@upatras.gr

Department of Cardiothoracic Surgery, Patras University School of Medicine, Rion 26500, Greece
}

\section{Biomed Central}

(C) 2012 Fragkidis; licensee BioMed Central Ltd. This is an Open Access article distributed under the terms of the Creative Commons Attribution License (http://creativecommons.org/licenses/by/2.0), which permits unrestricted use, distribution, and reproduction in any medium, provided the original work is properly cited.

\section{Results}

The results are summarized in Table 1 . We identified 29 patients whose cases were reported in 22 articles [1-22]. The mean age of the patients was 67 years, ranging from 48 to 83 years; $72 \%$ of patients $(n=21)$ were male; $66 \%$ of patients $(\mathrm{n}=19)$ had undergone left pneumonectomy; mean elapsed time between pneumonectomy and operation was 19 years, ranging from 9 months to 51 years.

All but one patient underwent one operation, apart from patient 22 who underwent two; therefore, 30 cardiac operations were performed on 29 patients. The most common operation performed was CABG alone $(\mathrm{n}=21,70 \%)$, followed by valvular surgery alone $(\mathrm{n}=7$, $23 \%)$ and combined CABG and valvular surgery $(\mathrm{n}=2$, $7 \%)$. Median sternotomy was the approach of choice in $80 \%$ of the cases $(n=24)$. Left thoracotomy was used in the rest $20 \%(n=6)$, which involved only patients with previous left specifically pneumonectomy. Six (20\%) 
Table 1 Summary of 29 Reported Patients In The Literature With Previous Pneumonectomy who Underwent CABG and/ or Valve Replacement/Repair Surgery*

\begin{tabular}{|c|c|c|c|c|c|}
\hline Author/Year & $\begin{array}{l}\text { Patient } \\
\text { No. }\end{array}$ & $\begin{array}{l}\text { Age/Gender/ } \\
\text { Site/Elapsed } \\
\text { time }\end{array}$ & Preoperative Data & Operation & $\begin{array}{l}\text { Postoperative } \\
\text { Complications/Course }\end{array}$ \\
\hline \multirow[t]{2}{*}{$\begin{array}{l}\text { Lecharpentier } \\
\text { et al [1]/ } 1988\end{array}$} & 1 & 66/M/Left/12 y & $\begin{array}{l}\mathrm{DLCO},(78 \%) ; \mathrm{PaO}_{2}, 80 \mathrm{mmHg} ; \\
\mathrm{PaCO}_{2}, 43 \mathrm{mmHg} ; \mathrm{pH}, 7.35\end{array}$ & $\begin{array}{l}\text { CABG: LIMA } \rightarrow \text { LADA (median } \\
\text { sternotomy, on-pump) }\end{array}$ & $\begin{array}{l}\text { Inotropic support, respiratory } \\
\text { failure, pneumothorax/ } \\
\text { Discharged on day } 10\end{array}$ \\
\hline & 2 & 66/F/Right/36 y & $\mathrm{DLCO},(95 \%)$ & $\begin{array}{l}\text { Mitral valve replacement, } \\
\text { tricuspid valve annuloplasty } \\
\text { (median sternotomy, } \\
\text { on-pump) }\end{array}$ & $\begin{array}{l}\text { Inotropic support, atrial } \\
\text { fibrillation/ Died on day } 12\end{array}$ \\
\hline $\begin{array}{l}\text { Medalion } \\
\text { et al [2]/1994 }\end{array}$ & 3 & 70/F/Left/40 y & $\mathrm{FEV}_{1}, 0.95 \mathrm{~L}(45 \%) ; \mathrm{FVC}, 1.3 \mathrm{~L}(52 \%)$ & $\begin{array}{l}\text { CABG: } 3 \text { SVGs, LIMA (median } \\
\text { sternotomy, on-pump) }\end{array}$ & None/Discharged on day 11 \\
\hline $\begin{array}{l}\text { Shibata } \\
\text { et al [3]/1994 }\end{array}$ & 4 & 67/M/Left/13 y & $\begin{array}{l}\mathrm{FEV}_{1},(77 \%) ; \mathrm{FVC},(55 \%) ; \text { room air } \\
\mathrm{PaO}_{2}, 92 \mathrm{mmHg} ; \mathrm{PaCO}_{2}, 45 \mathrm{mmHg}\end{array}$ & $\begin{array}{l}\text { CABG: } 3 \text { SVGs (median } \\
\text { sternotomy, on-pump) }\end{array}$ & None /Discharged on day 57 \\
\hline $\begin{array}{l}\text { Berrizbeitia } \\
\text { et al [4]/1995 }\end{array}$ & 5 & 61/M/Right/42 y & $\begin{array}{l}\mathrm{FEV}_{1}, 0.59 \mathrm{~L}(21 \%) ; \mathrm{FVC}, 1.27 \mathrm{~L}(32 \%) ; \\
\mathrm{DLCO},(48 \%) ; \text { room air } \mathrm{PaO}_{2} \\
77 \mathrm{mmHg} ; \mathrm{PaCO}_{2}, 48 \mathrm{mmHg} ; \mathrm{pH}, \\
7.40 ; \mathrm{TLC}, 2.97(49 \%) ; \mathrm{PAP} \\
\text { 25/14 mmHg }\end{array}$ & $\begin{array}{l}\text { CABG: } 3 \text { SVGs } \rightarrow \text { LADA, OMB, } \\
\text { PDA (median sternotomy, } \\
\text { on-pump) }\end{array}$ & None/Discharged on day 18 \\
\hline
\end{tabular}

\begin{tabular}{|c|c|c|c|c|c|}
\hline $\begin{array}{l}\text { Izzat } \\
\text { et al [5]/1995 }\end{array}$ & 6 & 65/M/Right/10 y & Not specified & $\begin{array}{l}\text { Mitral valve replacement } \\
\text { (median sternotomy, } \\
\text { on-pump) }\end{array}$ & $\begin{array}{l}\text { Postoperative hypotension; } \\
\text { pneumothorax; mediastinitis; } \\
\text { sepsis/Died on day } 12\end{array}$ \\
\hline $\begin{array}{l}\text { Demirtas } \\
\text { et al [6]/1995 }\end{array}$ & 7 & 63/M/Left/20 y & $\begin{array}{l}\mathrm{FEV}_{1}, 1.09 \mathrm{~L}(36 \%) ; \mathrm{FVC}, 1.36 \mathrm{~L}(36 \%) ; \\
\text { room air PaO } \mathrm{PaO}_{2}, 68 \mathrm{mmHg} \mathrm{PaCO}_{2 \prime} \\
36 \mathrm{mmHg} ; \mathrm{PAP}, 28 / 11 \mathrm{mmHg}\end{array}$ & $\begin{array}{l}\text { CABG: LIMA } \rightarrow \text { LADA } \\
\text { SVG } \rightarrow 1 O M G \text { (median } \\
\text { sternotomy, on-pump) }\end{array}$ & None /Discharged on day 7 \\
\hline $\begin{array}{l}\text { Soltanian } \\
\text { et al [7]/1998 }\end{array}$ & 8 & 70/F/Left/19 y & $\mathrm{FEV}_{1}, 1.06 \mathrm{~L} ; \mathrm{FVC}, 1.58 \mathrm{~L}$ & $\begin{array}{l}\text { CABG: SVG } \rightarrow \text { LADA (left } \\
\text { thoracotomy, on-pump) }\end{array}$ & $\begin{array}{l}\text { Respiratory failure; pulmonary } \\
\text { embolism; pneumonia /Diedon } \\
\text { day } 6\end{array}$ \\
\hline \multirow[t]{2}{*}{$\begin{array}{l}\text { Lippmann and } \\
\text { Au [8]/2000 }\end{array}$} & 9 & 68/M/Left/15 y & $\mathrm{FEV}_{1}, 1.65 \mathrm{~L}(56 \%) ; \mathrm{FVC}, 2.30 \mathrm{~L}(60 \%)$ & $\begin{array}{l}\text { CABG: } 3 \text { SVGs (median } \\
\text { sternotomy, on-pump) }\end{array}$ & $\begin{array}{l}\text { Postoperative bleeding } \\
\text { requiring re-exploration; } \\
\text { respiratory failure; atrial } \\
\text { fibrillation; hemothorax/ } \\
\text { Discharged on day } 48\end{array}$ \\
\hline & 10 & 73/M/Left/22 y & $\mathrm{FEV}_{1}, 1.65 \mathrm{~L}(53 \%) ; \mathrm{FVC}, 2.40 \mathrm{~L}(58 \%)$ & $\begin{array}{l}\text { CABG:SVG, LIMA (median } \\
\text { sternotomy, on-pump) }\end{array}$ & None / Discharged on day 9 \\
\hline $\begin{array}{l}\text { Golbasi } \\
\text { et al [9]/2001 }\end{array}$ & 11 & 58/M/Right/9 mo & $\begin{array}{l}\mathrm{FEV}_{1}, 1.42 \mathrm{~L}(50 \%) ; \mathrm{FVC}, 1.57 \mathrm{~L}(44 \%) ; \\
\text { room air } \mathrm{PaO}_{2}, 76 \mathrm{mmHg} \mathrm{PaCO}_{2} \\
38 \mathrm{mmHg} ; \mathrm{pH}, 7.51 \text {; PAP, } \\
35 / 18 \mathrm{mmHg}\end{array}$ & $\begin{array}{l}\text { CABG: } 3 \text { SVGs } \rightarrow \text { LADA, 1OMB, } \\
\text { PDA (median sternotomy, } \\
\text { on-pump) }\end{array}$ & $\begin{array}{l}\text { Respiratory failure / Discharged } \\
\text { on day } 12\end{array}$ \\
\hline $\begin{array}{l}\text { Diab } \\
\text { et al [10]/2001 }\end{array}$ & 12 & 64/M/Right/6 y & $\begin{array}{l}\mathrm{PaO}_{2}, 68 \mathrm{mmHg} ; \mathrm{PaCO}_{2}, 46 \mathrm{mmHg} ; \\
\mathrm{pH}, 7.38\end{array}$ & $\begin{array}{l}\text { CABG: SVG (median } \\
\text { sternotomy, on-pump) }\end{array}$ & $\begin{array}{l}\text { Pneumothorax / Discharged } \\
\text { on day } 20\end{array}$ \\
\hline \multirow[t]{2}{*}{$\begin{array}{l}\text { El-Hamamsy } \\
\text { et al [11]/2003 }\end{array}$} & 13 & 65/F/Right/51 y & $\mathrm{FEV}_{1}, 0.86 \mathrm{~L}(36 \%) ; \mathrm{FVC}, 1.37 \mathrm{~L}(44 \%)$ & $\begin{array}{l}\text { Mitral valve replacement, } \\
\text { tricuspid valve annuloplasty } \\
\text { (median sternotomy, } \\
\text { on-pump) }\end{array}$ & None / Discharged on day 6 \\
\hline & 14 & 71/F/Right/50 y & $\mathrm{FEV}_{1}, 0.60 \mathrm{~L}(28 \%) ; \mathrm{FVC}, 0.75 \mathrm{~L}(27 \%)$ & $\begin{array}{l}\text { CABG: SVGs (median } \\
\text { sternotomy, off-pump) }\end{array}$ & None / Discharged on day 7 \\
\hline $\begin{array}{l}\text { Kumar } \\
\text { et al [12]/2003 }\end{array}$ & 15 & 70/M/ Left/ 15 y & $\begin{array}{l}\mathrm{FEV}_{1}, 1.74 \mathrm{~L} ; \mathrm{FVC}, 3.18 \mathrm{~L} ; \text { room air } \\
\mathrm{PaO}_{2}, 62 \mathrm{mmHg} ; \mathrm{PaCO}_{2}, 37 \mathrm{mmHg} \\
\mathrm{K}_{\mathrm{CO},}(72 \%)\end{array}$ & $\begin{array}{l}\text { CABG: LIMA } \rightarrow \text { LADA } \\
\text { SVG } \rightarrow \text { PDA (median } \\
\text { sternotomy, off-pump) }\end{array}$ & None / Discharged on day 5 \\
\hline $\begin{array}{l}\text { Erdil } \\
\text { et al [13]/2004 }\end{array}$ & 16 & 51/M/ Right/ 17 y & 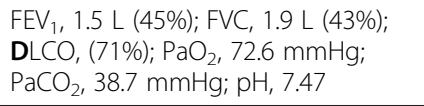 & $\begin{array}{l}\text { CABG: RA } \rightarrow \text { RCA RA } \\
(Y) \rightarrow L A D A, \text { OMB (median } \\
\text { sternotomy, on-pump) }\end{array}$ & None / Discharged on day 10 \\
\hline $\begin{array}{l}\text { Shanker } \\
\text { et al }[14] / 2005\end{array}$ & 17 & 80/M/ Left / 27 y & $\begin{array}{l}\mathrm{FEV}_{1}, 1.0 \mathrm{~L}(46 \%) ; \mathrm{DLCO} / \mathrm{NA},(53 \%) ; \\
\text { mean PAP, } 54 \mathrm{mmHg}\end{array}$ & $\begin{array}{l}\text { Mitral valve repair, aortic } \\
\text { valve replacement, CABG: } \\
\text { SVG } \rightarrow \text { LADA, diagonal } \\
\text { branch (median sternotomy, } \\
\text { on-pump) }\end{array}$ & None / Discharged on day8 \\
\hline
\end{tabular}


Table 1 Summary of 29 Reported Patients In The Literature With Previous Pneumonectomy who Underwent CABG and/ or Valve Replacement/Repair Surgery* (Continued)

\begin{tabular}{|c|c|c|c|c|c|}
\hline $\begin{array}{l}\text { Bernet } \\
\text { et al [15]/ } 2006\end{array}$ & 18 & 58/M/ Right /3 y & $\mathrm{FEV}_{1}, 1.41 \mathrm{~L}(59 \%) ; \mathrm{FVC}, 2.22 \mathrm{~L}(59 \%)$ & $\begin{array}{l}\text { CABG: LIMA } \rightarrow \text { LADA } \\
\text { SVG } \rightarrow \text { LCX, RCA (median } \\
\text { sternotomy, on-pump) }\end{array}$ & None / Discharged on day 7 \\
\hline $\begin{array}{l}\text { MH Us } \\
\text { et al [16]/2006 }\end{array}$ & 19 & 74/M/ Left /15 y & $\begin{array}{l}\mathrm{FEV}_{1}, 1.35 \mathrm{~L}(45 \%) ; \mathrm{FEV}_{1} / \mathrm{FVC} \text {, } \\
0.65(60 \%), \mathrm{PaO}_{2}, 64 \mathrm{mmHg} \\
\mathrm{PaCO}_{2}, 45 \mathrm{mmHg} ; \mathrm{pH}, 7.42\end{array}$ & $\begin{array}{l}\text { Mitral valve replacement, } \\
\text { subaortic membrane } \\
\text { resection (median } \\
\text { sternotomy, on-pump) }\end{array}$ & None / Discharged on day 7 \\
\hline $\begin{array}{l}\text { MH Us } \\
\text { et al [17]/2010 }\end{array}$ & 20 & 65/M/ Left /8 y & $\begin{array}{l}\mathrm{FEV}_{1}, 1.30 \mathrm{~L}(45 \%) ; \mathrm{FEV}_{1} / \mathrm{FVC}_{1} \\
0.60(50 \%) ; \mathrm{PaO}_{2}, 60 \mathrm{mmHg} ; \\
\mathrm{PaCO}_{2}, 48 \mathrm{mmHg}\end{array}$ & $\begin{array}{l}\text { CABG: SVG } \rightarrow \text { LADA, } \\
\text { circumflex (left thoracotomy, } \\
\text { off-pump) }\end{array}$ & None / Discharged on day 5 \\
\hline \multirow[t]{5}{*}{$\begin{array}{l}\text { Stoller } \\
\text { et al [18]/2007 }\end{array}$} & 21 & 54/F/ Left /3 y & $\mathrm{FEV}_{1}, 1.63(61 \%) ; \mathrm{FVC}, 2.03$ (61\%) & $\begin{array}{l}\text { CABG: } 3 \text { SVGs } \rightarrow \text { RCA, LADA, } \\
\text { LCX (emergent median } \\
\text { sternotomy, on-pump) }\end{array}$ & $\begin{array}{l}\text { Respiratory failure; pneumonia / } \\
\text { Discharged on day 26; } \\
\text { admitted } 8 \text { y later with } \\
\text { respiratory and congestive } \\
\text { heart failure }\end{array}$ \\
\hline & \multirow[t]{2}{*}{22} & \multirow[t]{2}{*}{$\begin{array}{l}48 / \mathrm{M} / \text { Left } / 18 \text { y } \\
\text { (before first } \\
\text { surgery), } 26 \text { y } \\
\text { (before second } \\
\text { surgery) }\end{array}$} & $\begin{array}{l}\text { First surgery: PAP, } 65 / 30 \mathrm{mmHg} \text {; } \mathrm{CO} \text {, } \\
6.7 \mathrm{~L} / \mathrm{min} \text {. No pulmonary function } \\
\text { tests available due to emergency of } \\
\text { situation }\end{array}$ & \multirow[t]{2}{*}{$\begin{array}{l}\text { Tricuspid and mitral valve } \\
\text { repair (re-sternotomy, } \\
\text { on-pump) }\end{array}$} & \multirow[t]{2}{*}{$\begin{array}{l}\text { Atrial fibrillation / Discharged } \\
\text { on postoperative day } 13\end{array}$} \\
\hline & & & $\begin{array}{l}\text { Second surgery: } \mathrm{FEV}_{1}, 1.36 \mathrm{~L}(37 \%) ; \\
\text { FVC, } 1.94(42 \%) ; \mathrm{FEV}_{1} / \mathrm{FVC}, 0.71 \\
(85 \%) ; \mathrm{RVSP}, 52 \mathrm{mmHg}\end{array}$ & & \\
\hline & 23 & 71/M/ Left /7 y & $\begin{array}{l}\mathrm{FEV}_{1}, 1.17 \mathrm{~L}(33 \%) ; \mathrm{FVC}, 1.86 \mathrm{~L}(40 \%) \\
\mathrm{FEV}_{1} / \mathrm{FVC}, 0.63(83 \%) ; \text { room air } \mathrm{PaO}_{2} \\
79 \mathrm{mmHg} ; \mathrm{PaCO}_{2}, 41 \mathrm{mmHg} \\
\mathrm{pH}, 7.46\end{array}$ & $\begin{array}{l}\text { Mitral valve replacement, } \\
\text { tricuspid valve annuloplasty } \\
\text { (median sternotomy, } \\
\text { on-pump) }\end{array}$ & $\begin{array}{l}\text { Hypotension and renal failure; } \\
\text { atrial fibrillation / Survived (no } \\
\text { further data) }\end{array}$ \\
\hline & 24 & 74/F/ Left/37 y & $\begin{array}{l}\mathrm{FEV}_{1}, 1.47 \mathrm{~L}(75 \%) ; \mathrm{FVC}, 1.83 \mathrm{~L}(70 \%) \\
\mathrm{FEV}_{1} / \mathrm{FVC}, 0.81(106 \%)\end{array}$ & $\begin{array}{l}\text { CABG: } 4 \text { SVGs } \rightarrow \text { LADA, lateral } \\
\text { circumflex, high lateral } \\
\text { circumflex, diagonal branch } \\
\text { (left thoracotomy, on-pump) }\end{array}$ & $\begin{array}{l}\text { None / Discharged on day } 6 ; \\
\text { experienced stroke on day } 18 ; \\
\text { died on day } 22\end{array}$ \\
\hline $\begin{array}{l}\text { Zhao } \\
\text { et al [19]/2008 }\end{array}$ & 25 & 57/M/ Left /7 y & $\mathrm{FEV}_{1}, 2.24 \mathrm{~L}(62 \%) ; \mathrm{FVC}, 3.21 \mathrm{~L}(70 \%)$ & $\begin{array}{l}\text { CABG: } 2 \text { SVGs } \rightarrow \text { LADA, OMB, } \\
\text { RCA (left thoracotomy, } \\
\text { off-pump) }\end{array}$ & None / Discharged on day 9 \\
\hline \multirow[t]{2}{*}{$\begin{array}{l}\text { Ghotkar } \\
\text { et al [20]/2008 }\end{array}$} & 26 & 71/M/ Left /18 y & $\begin{array}{l}\mathrm{FEV}_{1}, 1.1 \mathrm{~L}(42 \%) ; \mathrm{FVC}, 1.8 \mathrm{~L}(53 \%) ; \\
\mathrm{FEV}_{1} / \mathrm{FVC}, 0.79\end{array}$ & $\begin{array}{l}\text { CABG: SVG } \rightarrow \text { LADA, PDA } \\
\text { (median sternotomy, } \\
\text { on-pump) }\end{array}$ & $\begin{array}{l}\text { Excessive bleeding requiring } \\
\text { re-exploration; atelectasis / } \\
\text { Discharged on day } 17\end{array}$ \\
\hline & 27 & 77/F/ Right /13 mo & $\begin{array}{l}\mathrm{FEV}_{1}, 0.7 \mathrm{~L}(64 \%) ; \mathrm{FVC}, 0.9 \mathrm{~L}(63 \%) ; \\
\mathrm{FEV}_{1} / \mathrm{FVC}, 1.04\end{array}$ & $\begin{array}{l}\text { Aortic valve replacement } \\
\text { (median sternotomy, } \\
\text { on-pump) }\end{array}$ & None / Not specified \\
\hline $\begin{array}{l}\text { Stamou } \\
\text { et al }[21] / 2010\end{array}$ & 28 & 83/M/ Left /8 y & $\mathrm{FEV}_{1},(48 \%) ; \mathrm{DLCO},(77 \%)$ & $\begin{array}{l}\text { Aortic valve replacement, } \\
\text { CABG: SVGs (left thoracotomy, } \\
\text { on-pump) }\end{array}$ & None / Discharged on day 5 \\
\hline $\begin{array}{l}\text { Ushijima } \\
\text { et al [22]/2011 }\end{array}$ & 29 & $82 / M /$ Left /20 y & $\begin{array}{l}\mathrm{FEV}_{1}, 1.28 \mathrm{~L}(64 \%) ; \mathrm{FVC}, 1.89 \mathrm{~L}(64 \%) ; \\
\mathrm{PaO}_{2}, 85 \mathrm{mmHg} ; \mathrm{PaCO}_{2}, 43 \mathrm{mmHg} \\
\mathrm{pH}, 7.40\end{array}$ & $\begin{array}{l}\text { CABG: LIMA, RA }(Y) \rightarrow \text { LADA, } \\
\text { posterolateral artery (left } \\
\text { thoracotomy, off-pump) }\end{array}$ & None / Not specified \\
\hline
\end{tabular}

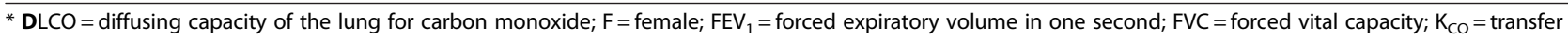
factor; $L A D A=$ left anterior descending artery; $L C X=$ left anterior circumflex artery; LIMA = left internal mammary artery; $M=$ male; OMB = obtuse marginal branch; $1 \mathrm{OMB}=$ first obtuse marginal branch; $\mathrm{PaO}_{2}=$ arterial oxygen partial pressure; $\mathrm{PaCO}_{2}=$ arterial carbon monoxide partial pressure; $\mathrm{PAP}=$ pulmonary arterial pressure; $\mathrm{PDA}=$ posterior descending artery; $\mathrm{RA}=$ radial artery; $\mathrm{RCA}=$ right coronary artery; RVSP = right ventricular systolic pressure; $S \mathrm{SG}=$ saphenous vein graft; $V A=$ alveolar volume; $(Y)=y$-graft. Percentiles in parentheses refer to percentiles of predicted values. Days mentioned in the table refer to postoperative days.

underwent Off-pump CABG (OPCAG). In 3 of these operations left thoracotomy was the preferred approach.

FEV1 percentiles of predicted values were reported preoperatively in 23 cases and the mean percentile was $49 \%$ of predicted, ranging from $21 \%$ to $77 \%$ of predicted. In addition, preoperative FVC percentiles of predicted values were provided in 19 cases and the mean percentile was $51 \%$ of predicted, ranging from $27 \%$ to $70 \%$ of predicted. Preoperative arterial blood oxygen levels were provided in 12 cases and mean value was $74 \mathrm{mmHg}$, ranging from 60 to $92 \mathrm{mmHg}$. For arterial blood carbon dioxide, whose preoperative levels were reported in 12 cases, mean levels were $42 \mathrm{mmHg}$, ranging from 36 to $48 \mathrm{mmHg}$. Of the 30 operations performed, 11 (37\%) were followed by complications, the most common being respiratory failure $(\mathrm{n}=5,17 \%)$, atrial fibrillation 
( $\mathrm{n}=4,13 \%$ of operations) and pneumothorax $(\mathrm{n}=3$, $10 \%)$, while 30 -day mortality rate was $13 \%(n=4)$.

\section{Discussion}

The current review covers the database up to date regarding coronary revascularization and valvular procedures via open heart surgery in previously pneumonectomised patients. During our search we identified three articles $[2,10,18]$ presenting a review of the subject. The first one by Medalion et al. [2] in 1994 was based on a worldwide survey of 118 members of the Society of Thoracic Surgeons, along with available data from the literature and one newly described patient. They presented collective data for 27 previously pneumonectomized patients who had undergone CABG and/or valve surgery. CABG was performed in $81 \%$ of cases, followed by mitral valve replacement in $19 \%$. There were reported difficulties in exposing the circumflex marginal branches of 2 patients with left pneumonectomy. The most common postoperative complication was pneumothorax in $11 \%$ of patients, followed and postpericardiotomy syndrome in $4 \%$, while the mortality rate was $7 \%$.

In the second article by Diab et al [10] in 2001, the authors searched the MEDLINE database to identify six previously pneumonectomized patients from the literature and added one newly described patient to their review. All seven patients had undergone CABG. Forty-three percent of patients developed postoperative complications, the most common of them being pneumothorax and respiratory failure requiring reintubation (29\%) and prolonged ventilation. Overall mortality was $14 \%$.

The third and most recent review was published by Stoller et al [18] in 2007. By searching the MEDLINE database from 1966 to 2006, they identified 15 patients with previous pneumonectomy who had undergone CABG and/or valve surgery, and also included 4 such patients from their institution's Cardiovascular Information Registry. A total of 20 operations were performed in the 19 reviewed patients. CABG accounted for 75\%, valve replacement or repair was performed in $20 \%$ and concomitant CABG and valve replacement/repair were performed in $5 \%$ of operations. Postoperative complications were reported in 50\%, with the most common being respiratory failure and pneumothorax, in $25 \%$ and $10 \%$ of operations respectively. The 30 -day mortality rate was $16 \%$. Our current review includes the 15 patients reviewed by Stoller et al [18] (patients 1-5, 7-15 and 17), as well as the 4 newly described patients by Stoller et al [18] (patients 21-24). We extend our review by adding 10 more patients from the available up to date literature (patients 6, 16, 18-20 and 25-29) and believe, therefore, that all reported cases have been included and evaluated in this review.
It is well known that previously pneumonectomised patients have substantially reduced pulmonary capacities [23]. Although there is not precise data, most pneumonectomies had been performed for malignancy. In the current series, mean preoperative FEV1 and FVC values were $49 \%$ and $51 \%$ of predicted values respectively. Thus, preoperative respiratory physiotherapy, as well as steroids, bronchodilators and antibiotics should be used to improve postoperative morbidity and mortality rates in this high-risk group [24,25] We also believe that proper re-staging of the disease, in those pneumonectomised for lung carcinoma, should be undertaken preferably using a Positron Emission Tomography scan.

Pneumonectomy also incurs marked anatomical changes in the thorax [26,27]. This may necessitate deviations from standard protocols regarding open-heart surgery. For instance, in patients with previous left pneumonectomy, the heart and great vessels shift into the left chest and rotate [27]. This means that exposure of key sites for cardiopulmonary bypass cannulation, revascularization and valvular surgery may be easier via a left thoracotomy rather than a standard median sternotomy $[7,18,19,21,22]$. Stamou et al. [21] highlighted easy access to the aorta, the aortic root and the coronary arteries approaching the heart through a left thoracotomy in patients with previous left pneumonectomy. Nonetheless, since the degree of mediastinal shift varies greatly for each patient [26], alternative sites should be used if standard aortic cannulation is not possible and preoperative imaging tests, mainly chest CT scan, should be performed to assess best exposure of target sites. In our review, 6 patients with previous left pneumonectomy, underwent surgery via left thoracotomy, 5 underwent CABG alone (patients 8,21, 24, 25 and 19) and 1 underwent combined CABG and aortic valve replacement (patient 28). Overall mortality rate for this subgroup of patients was $17 \%, \mathrm{n}=7$.

Another consideration in patients with previous pneumonectomy is the ability to establish cardiopulmonary bypass (CPB). Berrizbeitia et al [4] reported difficulty during cannulation of inferior vena cava (IVC) in a patient with previous right pneumonectomy, because acute angulation had resulted from the rightward displacement of the right atrium, which could not be followed by the fixed IVC. Accordantly, axillary artery and femoral vein may also be considered as cannulation sites in patients where median sternotomy may be problematic [21].

It is worth noting that in our review, 6 patients (14, $15,18,21,25$ and 29) OPCAB, 3 of them via left thoracotomy (patients 21, 25 and 29). OPCAB, according to recent studies $[28,29]$, has similar morbidity and mortality rates compared to standard CPB for CABG surgery, but boasts reduced incidence of systemic inflammatory response syndrome, blood clotting and blood loss, while 
claiming shorter ventilation and recovery periods. In previously pneumonectomised patients therefore, it may hold an advantage over $\mathrm{CPB}$, since these patients already have impaired pulmonary function [30] and are at higher risk for CPB-related complications [10]. Ushijima et al [22] stated that OPCAB reduces postoperative pulmonary complications and eliminates the need for compromise between central venous system and target coronary site exposure.

There have been objections in the past literature concerning the use of the internal thoracic artery (ITA) to perform CABG in previously pneumonectomised patients $[4,19,20]$. For instance, the ITA may be difficult to harvest from the side of pneumonectomy and the pedicled graft may fail to reach its target site due to heart dislocation. In addition, the ITA may be subjected to excess stress and tension by the hyper-inflated lung. Moreover, harvesting of the ITA on the side of the intact lung may cause damage to the phrenic nerve10, while postoperative pain associated with ITA harvesting may deteriorate pulmonary function [31]. Nonetheless, Stoller et al [18] favoured its use, claiming favorable experience with the graft. Also, Bernet et al [15] suggested harvesting of a skeletonized ITA or performing a "LIMA fissure" technique [32] to alleviate stress on the ITA. Out of 21 CABG operations performed in our review, ITA graft was used in 8 (38\%). Postoperative complications were reported in 2 of these cases and in 1 of them the outcome was fatal.

Prevalence of postoperative complications in the current series was $37 \%(n=11)$, with respiratory failure being the most common $(n=5)$, requiring prolong ventilation and tracheostomy. This is justified by the reviewed patients' compromised preoperative pulmonary reserves [23], along with the fact that anatomical changes of the chest may pose challenges on the surgical team, possibly leading to increased pump-related stress or even injury to chest structures [26]. Overall mortality rate in the current series was $13 \%$, slightly less than the $16 \%$ reported in the last review by Stoller et al [18], but still high compared to patients with no such a severe comorbidity undergoing CABG or valve surgery [33,34]. Furthermore, major adverse cardiac and cardiovascular effects were not observed in a significantly higher rate among this cohort of patients. Unfortunately, there is no data to detect the long term prognosis, since most of the cases were focused on early postoperative outcome.

\section{Conclusion}

In conclusion, the current series extends the previous review by Stoller et al [18], summarizing the available data on 29 previously pneumonectomised patients who underwent $30 \mathrm{CABG}$ and/or valvular operations. The gathered experience suggests that a carefully planned surgical strategy that incorporates modern techniques to alleviate patient stress, combined with specific standards regarding preoperative and postoperative management, contribute to successfully perform open heart revascularization and/or valvular procedures with acceptable but still high morbidity and mortality rates in previously pneumonectomised patients. Finally, in view of the new era of transfemoral aortic valve insertion (TAVI), this review it is likely to stimulate the existing argument as to whether, in these patients, a TAVI procedure should be preferred to an open aortic valve replacement.

\section{Competing interests}

The author(s) declare that they have no competing interests.

\section{Authors' contributions}

AF collected the data and wrote the manuscript. AF helped in collecting the data. DD revised the manuscript. All authors read and approved the final manuscript.

Received: 1 April 2012 Accepted: 23 September 2012

Published: 10 October 2012

\section{References}

1. Lecharpentier Y, Zerr C, Merrille C, Lebreton P, Khayat A: Chirurgiecardiaque chez deux patients anterieurement pneumonectomises. Cah Anesthesiol 1988, 36:645-647.

2. Medalion B, Elami A, Milgalter E, Merin G: Open heart operation after pneumonectomy. Ann Thorac Surg 1994, 58:882-884.

3. Shibata T, Suehiro S, Kimura E, Nishizawa K, Minamimura H, Kinoshita H: Coronary artery bypass grafting 13 years after pneumonectomy. NipponKyobu-Geka-Gakkai-Zasshi 1994, 42:1105-1107.

4. Berrizbeitia LD, Anderson WA, Laub GW, McGrath LB: Coronary artery bypass grafting after pneumonectomy. Ann Thorac Surg 1994, 58:1538-1540.

5. Izzat MB, Regragui IA, Angelini GD: Mitral valve replacement after previous right pneumonectomy. Ann Thorac Surg 1995, 59:222-224.

6. Demirtas MM, Akar H, Kaplan M, Dagsali S: Coronary artery bypass operation after pneumonectomy. Ann Thorac Surg 1995, 60:232-233.

7. Soltanian H, Sanders JH, Robb JC, Marrin CA: Hybrid myocardial revascularization after previous left pneumonectomy. Ann Thorac Surg 1998, 65:259-260.

8. Lippmann M, Au J: Coronary artery bypass surgery after previous pneumonectomy. Scand Cardiovasc J 2000, 34:541-542.

9. Golbasi I, Turkay C, Sahin N, Oz N, Akbulut E, Gulmez H, Bayezid O: Coronary artery bypass grafting nine months after pneumonectomy. Tex Heart Inst J 2001, 28:146-148.

10. Diab KA, Khatib MF, Obeid M, Jamaleddine GW: Coronary artery bypass grafting after pneumonectomy. Eur J Cardio Thorac Surg 2001, 19:362-364.

11. El-Hamamsy I, Stevens LM, Perrault LP, Carrier M: Right pneumonectomy and thoracoplasty followed by coronary artery bypass grafting and mitral valve replacement. J Thorac Cardiovasc Surg 2003, 125:215-216.

12. Kumar P, Swift SJ, Athanasiou T, Nelson JS, Glenville B: CABG 15-years after left pneumonectomy: feasibility of off-pump approach. Cardiovasc Surg 2003, 11:305-307.

13. Erdil N, Nisanoglu V, Toprak HI, Erdil FA, Kuzucu A, Battaloglu B: Arterial myocardial revascularization using bilateral radial artery 17 years after right pneumonectomy. Tex Heart Inst J 2004, 31:96-98.

14. Shanker VR, Yadav S, Hodge AJ: Coronary artery bypass grafting with valvular heart surgery after pneumonectomy. ANZ J Surg 2005, 75:88-90

15. Bernet FH, Reineke DC, Grapow MT, Zerkowski HR: OPCAB surgery after right pneumonectomy. J Card Surg 2006, 21:92-93.

16. Us MH, Arslan Y, Ozbek C, Basaran M, Yildiz Y, Ogus T, Isik O: Coronary artery bypass grafting after left pneumonectomy. JCVA 2006, 20:709-711.

17. Us MH, Ugurlucan M, Basaran M, Selimoglu O, Kocailic A: Mitral valve replacement and subaortic membrane resection following pneumonectomy. Case Reports in Medicine 2010, 480703:3 pages. 
18. Stoller JK, Blackstone E, Petterson G, Mihaljevic T: Coronary artery bypass graft and/or valvular operations following prior pneumonectomy: report of four new patients and review of the literature. Chest 2007, 132:295-301.

19. Zhao $B Q$, Chen RK, Song JP: Coronary artery bypass grafting after pneumonectomy. Tex Heart Inst J 2008, 35:470-471.

20. Ghotkar SV, Aerra V, Mediratta N: Cardiac surgery in patients with previous pneumonectomy. J Cardio Thorac Surg 2008, 3:11.

21. Stamou S, Murphy MC, Kouchoukos NT: Aortic valve replacement and coronary artery bypass via left anterior thoracotomy after previous left pneumonectomy. J Thorac Cardiovasc Surg 2010, 140:719-720.

22. Ushijima T, Kikuchi Y, Ikeda C, Takata M, Yamamoto Y, Watanabe G: Totally arterial off-pump coronary artery bypass grafting after pneumonectomy. Ann Thor Cardiovasc Surg 2011, 17:320-322.

23. Nugent AM, Steele IC, Carragher AM, McManus K, McGuigan JA, Gibbons JR, Riley MS, Nicholls DP: Effect of thoracotomy and lung resection on exercise capacity in patients with lung cancer. Thorax 1999, 54:334-338.

24. Hulzebos EH, Helders PJ, Favie NJ, De Bie RA, de la Riviere AB, Meeteren NL: Preoperative Intensive inspiratory muscle training to prevent postoperative pulmonary complications in high-risk patients undergoing CABG surgery. A Randomized Clinical Trial. JAMA 2006, 15:1851-1857.

25. Doyle RL: Assessing and modifying the risk of postoperative pulmonary complications. Chest 1999, 115:77S-81S.

26. Wutschke IB, Paulsen F, Stovesandt D, Holzhausen HJ, Heine HJ, Peschke E: Anatomical changes after pneumonectomy. Ann Anat 2011, 193:168-172.

27. Smulders SA, Holverda S, Noordegraaf AV, Bosch HC, Post JC, Marcus JT, Smeenk FW, Postmus PE: Cardiac function and position more than 5 years after pneumonectomy. Ann Thorac Surg 2007, 83:1986-1992.

28. Puskas JD, Williams WH, O'Donnell R, Patterson RE, Sigman SR, Smith AS, Baio KT, Kilgo PD, Guyton RA: Off-pump and on-pump coronary artery bypass grafting are associated with similar graft patency, myocardial ischemia, and freedom from reintervention: long term follow-up of a randomized trial. Ann Thorac Surg 2011, 91:1836-1843.

29. Sidhu V, Varaday S: Anaesthesia for off-pump coronary artery bypass surgery. Anaesth and ICM 2006, 7(8):281-283.

30. Smulders SA, Smeenk FW, Heijnen ML, Postmus PE: Actual and predicted postoperative changes in lung function after pneumonectomy. A retrospective analysis. Chest 2004, 125:1735-1741.

31. Cohen AJ, Moore P, Jones C, Miner TJ, Carter WR, Zurcher RP, Lupkas R, Edwards FH: Effect of internal mammary harvest on postoperative pain and pulmonary function. Ann Thorac Surg 1993, 56:1107-1109.

32. Rao P, Natarajan K, Morritt G: "LIMA fissure" for a tension-free IMA graft in emphysema. Ann Thorac Surg 1997, 63:561-562.

33. Ferris TG, Torchiana DF: Public release of clinical outcomes data-online CABG report cards. N Eng J M 2010, 17:1593-1595.

34. Ambler G, Omar RZ, Royston P, Kinsman R, Keogh BE, Taylor KM: Generic, simple risk stratification model for heart valve surgery. Circulation 2005, 112:224-231.

doi:10.1186/1749-8090-7-110

Cite this article as: Fragkidis et al:: Coronary Artery bypass grafting and/ or valvular surgery in patients with previous pneumonectomy. Journal of Cardiothoracic Surgery 2012 7:110.

\section{Submit your next manuscript to BioMed Central and take full advantage of:}

- Convenient online submission

- Thorough peer review

- No space constraints or color figure charges

- Immediate publication on acceptance

- Inclusion in PubMed, CAS, Scopus and Google Scholar

- Research which is freely available for redistribution

Submit your manuscript at www.biomedcentral.com/submit 